\title{
INSTITUTIONAL DETERMINANTS OF HOUSEHOLD SAVINGS IN POLAND
}

\author{
Anna Magdalena KORZENIOWSKA
}

\begin{abstract}
The article analyses the influence of institutional factors on saving in one of the poorest regions in Poland, which is Lubelskie voivodeship. The research was conducted on the basis of institutional saving theory by M. Sherraden. The data were collected at the beginning of 2018 via a survey of household representatives and investigated using statistical methods such as factor analysis, parallel of averages and correlation coefficients. The conclusion drawn is that the institutional saving theory is not applicable exclusively in rich countries due to prevalence of other than institutional factors influencing household savings. Although the respondents view institutional factors as important, they do not use them as sole determinants of their behaviour and decisions in the saving process.
\end{abstract}

Keywords: Households saving, saving factors, institutional theory of saving

JEL Classification: D14, E14, E21

\section{Introduction}

During the last several years, a significant increase of interest in household finance has been observed (Campbell, 2006), particularly in saving. Saving is considered an important factor of economic growth, and national saving is the essential source of financing of investments in sustainable developing economies. Furthermore, private saving, which mostly consists of household savings, is an important source of stable capital for the financial system in times of crisis. After 2008, in some economies in the European Union, a decrease of the share of household savings in private saving has been observed at the expense of corporate saving. This is the case in Poland (Liberda, 2015). What is more, the trends of saving rates from the macro and the micro point of view are opposite. While the microeconomic household savings rate in Poland is rising, at the same time, the macroeconomic household saving rate is decreasing. In this context, the recognition of determinants of savings is

* PhD, Maria Curie-Skłodowska University, Faculty of Economics, Department of Banking, anna.korzeniowska@umcs.lublin.pl, ORCID: 0000-0001-9809-5260.

To cite this article: Korzeniowska, A. M. (2019). Institutional Determinants of Household Savings in Poland. Journal of Research in Business, 4(1), 55-63. DOI: 10.23892/JRB.2019453295 
especially important so that using positive influences on them can strengthen the saving process in the country.

Considering all this, the aim of this article is to determine the influence of institutional factors on the household savings process in Poland. The author hypothesizes that the influence of institutional factors on the saving process appears insignificant in the Polish economy.

The first part of the article introduces the institutional theory of saving. This is followed by the presentation of research on the importance of institutional determinants to individuals, which was run in Lubelskie voivodeship. The final section contains conclusions.

\section{Institutional Theory of Saving}

On the basis of different economic theories, individual theories of saving and asset accumulation have emerged. From neoclassical economics, the life cycle hypothesis by Ando and Modligliani (1963) was proposed, followed by Friedman's permanent income hypothesis (1957). These scientists focus on a long-term financial situation of the household as the main determinant of their decisions on saving.

From another point of view, as stated in the works of G. Katona and other psychological and sociological theories, economic behaviours are conditioned by motives, aspirations and expectations. G. Katona (1975) argued that saving consists of two set of factors-ability to save and willingness to save. The psychological theories of saving are closely followed by behavioural theories (Beverly, \& Sherraden, 1999).

In opposition to these theories are works of institutionalists such as T. Veblen and J. K. Galbraith (Green, 1991). They refuse to see an individual in isolation from society and treat a saving process as part of the total flow of consumer spending. Institutional economics emphasizes the need for broader study of institutions. According to this theory, institutions are individuals, firms, states and social norms. Institutionalists also view markets as a result of the complex interactions of these various institutions. Consequently, household saving behaviour is shaped by the saving process.

Finally, the institutional theory of saving posited by M. Sherraden in 1991 states that saving is a result of structured arrangements that involve explicit connections, rules and incentives (Curley, Ssewamala, \& Sherraden, 2009). Institutions are understood as laws and other formal mechanisms. They are formal and purposeful, have a defined structure and rules, and are designed to alter behaviours and outcomes for individuals (Sherraden, \& Barr, 2005). This theory usually deals with less developed economies or poorer/less wealthy households. That is why this article focuses on one of the poorest regions in Poland.

The main assumption of the institutional saving theory is that some institutional aspects have effects on asset accumulation. Specifically, seven institutional determinants are identified: access, information, incentives, facilitation, expectations, restrictions and security (Han, \& Sherraden, 
2009). Access means eligibility and practicality. It refers to financial market development, the number of institutions and the number of access points per inhabitant. The easier access is, the higher savings tend to be. Information is understood as ease of information access. It requires financial education as well as information on instruments and institutions provided by media and other sources. Incentives represent efforts to motivate individuals to save, e.g. tax relief, higher rates of return or subsidies connected with particular instruments and saving programs or employers' participation in saving programs, inter alia, by matching up employees' payments. Facilitation means institutional arrangements providing mechanisms to make saving more manageable, e.g. online services, automatic enrolling in programs, mostly "automatisation". Expectations are understood as suggestions about goals or match caps, profit expected from investments and specific goals to achieve through saving. Restrictions are prohibitions in access to and use of collected saving, e.g. limits referring to amounts and aims of saving as well as security allowing for lower risk in assets holding.

\section{The Perception of Saving Institutional Factors}

Poland is recognised as one of the less developed countries within the European Union, although since 2018, it has ceased to be ranked as an emerging market because of its financial market growth. The Lubelskie voivodeship is one of 16 voivodeships in Poland, it is in the Eastern Poland and-together with Podlaskie and Podkarpackie-it belongs to the poorest regions in the country (measured by GDP per capita), closely followed by Świętokrzyskie and Kujawsko-Pomorskie. According to the Central Statistical Office data for 2016, the disposable income per capita of households in this voivodeship is about $88 \%$ of the country average (Central Statistical Office, 2017a), and its GDP per capita is only $68,9 \%$ of the average (Central Statistical Office, 2017b). It is only reasonable to investigate whether under such circumstances the institutional saving theory applies to the households in Lubelskie voivodeship.

The research to analyse household finance was conducted in the voivodeship at the beginning of 2018 with the usage of the anonymous questionnaire. For this article, only respondents between 18 and 65 years of age who declared active employment were considered. In that way, the sample of 223 individuals was selected, each of whom represented one household from Lubelskie voivodeship. Considering, that there are 741.6 thousand households in analysed area, that allows to run statistical analysis with level of confidence of approximately $95 \%$ and the expected error rate $6 \%$. The respondents differed by gender, age, place of living and education. They also declared the size of their household measured by the number of its members, and they were asked to assess their financial situation. All calculations were run with the usage of IBM SPSS Statistics ver. 24.

Each respondent was asked to mark every single institutional factor individually on a scale from 0 (not important factor) to 10 (extremely important factor). The analysis was divided into three parts, and each of them answered one of three questions.

a) Can institutional factors be assigned to separate groups, or should they be considered as one integral group? 
a) What is the assessment of institutional factors by the respondents?

b) Is there a statistical correlation between the respondents' perception of institutional factors and both demographic and economic characteristics of the respondents?

\subsection{Internal Integrity of Institutional Factors as a Group}

As mentioned in the introduction, the institutional saving theory states that particular institutional factors can be divided into three groups: explicit connections, rules and incentives. To determine division of institutional factors in reference to the respondents, factor analysis was run. The principal components matrix presents only one component with the results shown in Table 1.

Table 1: Principal Components Matrix

\begin{tabular}{lll}
\hline & Component 1 \\
\hline Information & .813 \\
Incentives & .798 \\
Expectations & .795 \\
Facilitation & .762 & \\
Access & .755 & \\
Restrictions & .745 & \\
Security & .736 & \\
& & \\
K-M-O test & .867 \\
\hline Bartlett test & & 515.336 \\
& Approx. chi-sqr. & 21 \\
& df & .000 \\
\hline
\end{tabular}

Source: own calculations on the basis of the respondents' answers.

In the next step, several factor analyses were run to determine if institutional factors can be divided into groups depending on different characteristics of the respondents. The three groups, as in the original theory, were identified only in two cases: people whose savings equals 6-12 months of their income and people who save regularly but without a specific plan or goal. In other cases, the analysis allowed dividing factors into two groups or to present them as only one group. The distinctive factors usually were security, expectations, access and restrictions for analysing the respondents by their economic situation self-assessment.

The results may suggest that the behaviour of the respondents does not follow the pattern presented in the theory. This is further confirmed by the fact that all institutional factors are positively correlated with each other. This leads to the conclusion that further research is necessary to assess the influence of institutional factors on saving in Poland, particularly in Lubelskie voivodeship. 


\subsection{Evaluation of Institutional Determinants by Households}

To assess the importance of institutional factors for the respondents, the average marks for each factor were calculated. The outcome is presented in Table 2.

Table 2: Significance of Institutional Factors (Average Mark)

\begin{tabular}{ll}
\hline Institutional factor & Average mark \\
\hline Security & 7.00 \\
Incentives & 6.37 \\
Restrictions & 6.26 \\
Expectations & 6.21 \\
Information & 6.01 \\
Access & 5.93 \\
Facilitation & 5.68 \\
\hline Source: own calculations on the basis of the respondents'
\end{tabular}

The results imply that the respondents assess the importance of analysed factors above average, with security of assets being the most important. Facilitation with the score of 5.68 is considered the least important. This result stems from the significant lack of such facilities in Poland.

The best way to determine which factors influence saving the most is to compare the respondents' answers with the value of their reported savings and their attitude toward saving which they prefer.

Table 3: Significance of Institutional Factors by Declared Saving of Respondents

\begin{tabular}{|c|c|c|c|c|c|c|c|c|c|}
\hline \multirow[b]{2}{*}{ Institutional factor } & \multicolumn{6}{|c|}{ Saving volume } & \multicolumn{3}{|c|}{$\begin{array}{l}\text { Kruskal-Wallis test, grouped by } \\
\text { saving value }\end{array}$} \\
\hline & 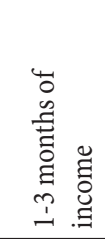 & 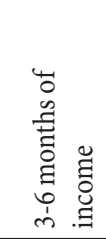 & 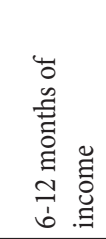 & 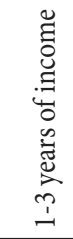 & 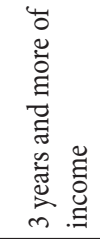 & 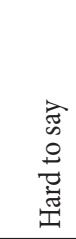 & 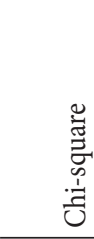 & 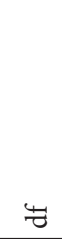 & 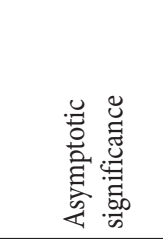 \\
\hline Access & 5.78 & 5.64 & 6.17 & 6.6 & 5.75 & 5.52 & 4.198 & 5 & 0.521 \\
\hline Information & 6.06 & 5.36 & 5.75 & 6.8 & 7.75 & 5.19 & 9.142 & 5 & 0.104 \\
\hline Incentives & 6.19 & 6.07 & 6.33 & 6 & 6.75 & 4.43 & 7.034 & 5 & 0.218 \\
\hline Facilitation & 5.47 & 5.93 & 5.08 & 5.2 & 6.75 & 4.9 & 8.629 & 5 & 0.125 \\
\hline Expectations & 5.86 & 5.57 & 5.75 & 6.1 & 6 & 4.38 & 13.549 & 5 & 0.019 \\
\hline Restrictions & 6.03 & 5.79 & 5.75 & 6.2 & 6.5 & 5.29 & 2.428 & 5 & 0.787 \\
\hline Security & 6.83 & 6.43 & 7.75 & 6.6 & 7.25 & 5.57 & 4.777 & 5 & 0.444 \\
\hline
\end{tabular}

Source: own calculation on the basis of the respondents' answers. 
In the questionnaire, the respondents were asked to point out the value of their savings in relationship to their monthly income. Their responses are presented in Table 3. The largest group of respondents (35.9\%) declared they had savings not larger than their 3-month income, which means that they do not reach the financial security buffer. It is assumed that to provide financial security in case of emergency, the household should be in possession of savings with a minimum value of its 3-month income. The next group consisted of respondents who did not declare their saving value either because they do not know it or they do not want to reveal it. This group included 53 persons, which accounts for $23.8 \%$ of the sample. For the other groups, the number of respondents falls with the extension of the period covered by saving volume. Thus, $14.3 \%$ of the respondents had savings of between 3 to 6 months of income, 12.6\% had savings of between 6 to 12 months of income, $8.4 \%$ had savings of between 1-3 years of income and 5.4\% of the respondents declared that their savings are greater than their 3-year income.

As can be observed, institutional factors seemed the most important for the respondents possessing the highest volume of saving and the least important for those who did not declare their saving value. These apparent differences between respondents were verified using Kruskal-Wallis test. It appears that the assessment of institutional factors varies significantly only in the case of expectations, while with the other factors, the differences are statistically insignificant.

In the questionnaire, the respondents were asked to point out their prevailing behaviours toward saving. The options were as follows.

1. I do not save- $4.5 \%$ of the answers.

1. I spend everything on current needs, do not put by anything, do not invest (spend everything) $-6.7 \%$ of the answers.

2. I usually devote everything to current needs, but from time to time, I manage to save something (save from time to time)-25.1\%.

3. In addition to current expenses, I try to save some funds on a regular basis (try to save regularly)-34.1\%.

4. I save a certain amount of money in addition to current expenses each month (save regularly) $-17.5 \%$.

5. I allocate funds for consumption and savings in advance, but I have no specific purpose to save and plan to use financial instruments (save without a goal) $-6.7 \%$.

6. In advance, I allocate funds for consumption and savings, which I invest in planned financial instruments (planned saving) $-5.4 \%$.

Once again, the average marks were calculated for each of the institutional factors, this time dividing the respondents by saving behaviours (Table 4). 
Table 4: Significance of Institutional Factors by Saving Behaviour of Respondents

\begin{tabular}{|c|c|c|c|c|c|c|c|c|c|c|}
\hline \multirow[b]{2}{*}{ Institutional factor } & \multicolumn{7}{|c|}{ Type of saving behaviour } & \multicolumn{3}{|c|}{$\begin{array}{c}\text { Kruskal-Wallis test, grouped by } \\
\text { saving behaviour }\end{array}$} \\
\hline & 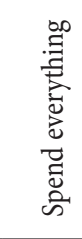 & 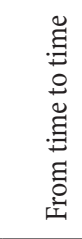 & 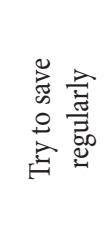 & 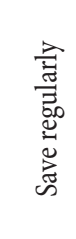 & 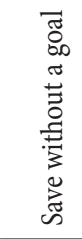 & 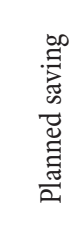 & 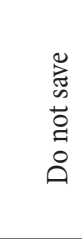 & 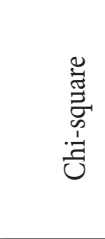 & $\Psi$ & 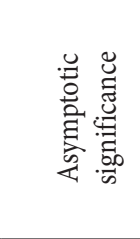 \\
\hline Access & 5.40 & 5.45 & 6.08 & 6.24 & 5.90 & 6.56 & 3.38 & 16.559 & 6 & 0.011 \\
\hline Information & 6.10 & 5.26 & 6.14 & 5.64 & 6.50 & 6.33 & 3.88 & 15.262 & 6 & 0.018 \\
\hline Incentives & 5.70 & 5.55 & 6.80 & 5.72 & 6.30 & 4.67 & 5.13 & 8.877 & 6 & 0.181 \\
\hline Facilitation & 6.00 & 5.34 & 5.69 & 5.24 & 6.20 & 4.89 & 2.88 & 9.485 & 6 & 0.148 \\
\hline Expectations & 5.90 & 5.21 & 6.29 & 5.36 & 6.20 & 7.22 & 2.88 & 23.010 & 6 & 0.001 \\
\hline Restrictions & 6.10 & 6.05 & 6.39 & 5.52 & 5.40 & 6.67 & 3.25 & 9.143 & 6 & 0.166 \\
\hline Security & 6.70 & 6.42 & 7.82 & 6.52 & 7.00 & 6.67 & 5.13 & 14.882 & 6 & 0.021 \\
\hline
\end{tabular}

Source: own calculation on the basis of the respondents' answers.

From this perspective, the differences between the respondents are visibly higher. The calculated average marks for analysed institutional factors range from 2.88 to 7.82 . The lowest marks are among the respondents declaring no savings, although some incentives and security of assets can prompt them to start. For persons who plan their saving with the use of dedicated financial instruments, expectations are very important (7.22), while incentives and facilitation are marked below the average. In this case, statistically significant differences between average marks are among four institutional factors, i.e. access, information, expectations and security.

\subsection{Correlation of Institutional Construct with Demographic Variables}

The last part of this analysis focuses on the correlations between the evaluation of institutional factors and the respondents' characteristics. Variables such as age, gender, place of living, educational level of the respondents and self-assessment of their financial situation were considered. The correlations were measured with the use of Kendall coefficient because the characteristics of the respondents are non-parametric. The calculations established that the statistically significant correlations were observed only in six cases in Table 5, all of them positive.

It becomes evident that the connection between the respondents' characteristics and their assessment of institutional factors is very low. None of these cases indicates that Tau b coefficient is higher than 0.15. In three out of six cases, the correlation refers to expectations. That means that this factor's mark differs between women and men. It also rises along with the education level and financial situations of the respondents. Another institutional factor that rises in importance along with the respondents' education level is security. 
Table 5. Statistically Significant Correlation Observed between the Institutional Factors and the Respondents' Characteristics

\begin{tabular}{lcc}
\hline Institutional factor & Variable differentiating respondents & Tau b Kendall \\
\hline Access & Self-assessment of financial situation & $0.146^{* *}$ \\
Facilitation & Place of living & $0.148^{* *}$ \\
Expectations & Self-assessment of financial situation & $0.118^{\star}$ \\
Expectations & Education level & $0.131^{\star}$ \\
Expectations & Gender & $0.146^{*}$ \\
Security & Education level & $0.133^{\star}$ \\
\hline
\end{tabular}

${ }^{*} \mathrm{p}=0.05,{ }^{* *} \mathrm{p}=0.01$

Source: own calculation on the basis of the respondents' answers.

The same tendency can be observed between the financial situation and access to both financial instruments and institutions. As for facilitation, it is positively correlated with the place of living, which means the bigger the city, the more important this institutional factor is.

\section{Conclusion}

Institutional factors of saving are perceived by individuals as essential determinants to undertake saving. The most important institutional determinant of saving is the security of allocated assets, followed by incentives. This confirms the common behaviour in which people tend to locate their savings securely and profitably. On the other hand, the least important is facilitation. This is so probably because Polish financial services are highly technologically advanced and electronic access, mostly online, is common. With such characteristics of the market, people do not consider electronic access advantageous. Moreover, there are no programs supporting saving products by automatic enrolment.

However, the research implies that the opinions of household representatives are not followed by real activity. The institutional factors, although considered important, are not crucial in households' decisions on the saving process. That is proved by the lack of correlation between institutional factors and volume of saving. The only two statistically significant correlations measured with Tau b Kendal are between responses "hard to say" (what my saving volume is) and both incentives $(-0.155 ; \mathrm{p}=0.05)$ and expectations $(-0.200 ; \mathrm{p}=0.01)$.

After dividing the respondents into groups by their saving volume or by their behaviour, it emerged that the statistically significant differences in viewing the factors influencing saving are expectation, security, access to financial products and information about them. 
Thus, the research indicates that the institutional determinants should be taken into consideration while investigating household saving behaviour, but it has to be analysed together with other factors such as psychological or sociological ones. It is important to take into account the influence of institutional factors while constructing fiscal or monetary policy for the country's economy. Given the example of Lubelskie voivodeship, we can imply that the validity of institutional factors is relatively lower in high and middle high income countries such as Poland, even in its poorest regions, compared to low income countries where this theory was developed and put into use.

\section{References}

Ando, A. and Modigliani, F. (1963). The "Life-Cycle" Hypothesis of Saving: Aggregate Implications and Tests. American Economic Review, 53, 55-84.

Campbell, J. Y. (2006). Household Finance. The Journal of Finance, 61(4), 1553-1604. https://doi.org/10.1111/ j.1540-6261.2006.00883.x

Central Statistical Office. (2017a). Sytuacja gospodarstw domowych w 2016 r. w świetle wyników badania budżetów gospodarstw domowych (Situation of households in 2016 in accordance with results relating to research analysing household budgets). Warsaw.

Central Ststistical Office. (2017b). Wstępne szacunki produkt krajowy brutto według województw w $2016 \mathrm{r}$. (Draft estimates of Gross Domestic Product by voivodeships in 2016).Katowice.

Curley, J., Ssewamala, F., \& Sherraden, M. (2009). Institutions and savings in low-income households. Journal of Sociology and Social Welfare, 36(3), 9-32.

Friedman, M. (1957). The Permanent Income Hypothesis. In A Theory of the Consumption Function (Vol. I, pp. 20-37). Princeton University Press. https://doi.org/10.1016/S0304-3932(98)00063-4

Green, F. (1991). Institutional and other unconventional theories of saving. Journal of Economic Issues, 25(1), 93-113. Retrieved from http://www.jstor.org/stable/4226376

Han, C.-K., \& Sherraden, M. (2009). Attitudes and Saving in Individual Development Accounts: Latent Class Analysis. Journal of Family and Economic Issues, 30(3), 226-236. https://doi.org/10.1007/ s10834.009.9157-8

Katona, G. (1975). Psychological economics. Psychological economics. Oxford, England: Elsevier.

Liberda, B. (2015). Macroeconomic Saving in Poland. Ekonomista, (4), 437-451.

Sherraden, M., \& Barr, M. S. (2005). Institutions and inclusion in saving policy. In E. N. Retsinas, \& E. Belsky (Ed.), Building Assets, Building Credit: Creating Wealth in Low-Income Communities. Brookings Press. 